\title{
TANGGUNG JAWAB PERUSAHAAN JASA EKSPEDISI ATAS KETERLAMBATAN PENGIRIMAN BARANG (Studi Penelitian di PT. Jalur Nugraha Ekakurir Cabang Stabat)
}

\author{
1Habib Hamed, 2Fatahillah, ${ }^{2}$ Tri Widya Kurniasari \\ Email: habibhamed99@gmail.com \\ ${ }^{1}$ Mahasiswa Fakultas Hukum, Universitas Malikussaleh \\ ${ }^{2}$ Dosen Fakultas Hukum, Universitas Malikussaleh
}

\begin{abstract}
The number of people who send goods makes expedition services grow rapidly, as evidenced by the number of expedition services, one of which is PT. JNE Stabat. The rights and obligations of PT. JNE Stabat are of course regulated in Law Number 8 of 1999 concerning of Consumer Protection. The problems that will be discussed in this thesis are the rights and obligations of the parties in the goods delivery agreement and the responsibilities of PT. JNE Stabat if there is a delay in the delivery of the goods. The aim of this study is to provide an understanding and knowledge to the public regarding the protection obtained in the event of default in the delivery of goods and to increase the awareness of business actors about the importance of legal protection for consumers. The research method used in this study is empirical juridical research methods with a library and field approach. The library approach is used to obtain theoretical secondary data, while the field approach is used to obtain primary data through an interview process with respondents and informants. The results of this study explain that the rights and obligations of PT. JNE Stabat is contained in the delivery receipt, PT. JNE Stabat also provides compensation for delays in the amount of shipping costs that have been agreed upon, and only applies to Super Speed product services.
\end{abstract}

Keyword: Responsibility, Delivery. Default 


\section{PENDAHULUAN}

Perkembangan ilmu pengetahuan berkembang di setiap sektor pembangunan, salah satunya sektor usaha dan ekonomi. Perkembangan ilmu pengetahuan ini berdampak pada kebutuhan primer maupun sekunder masyarakat. Dengan adanya kemajuan ilmu pengetahuan, masyarakat memiliki keinginan agar sesuatu yang diinginkan terpenuhi secara cepat. Salah satunya dalam pengiriman barang. Perdagangan yang meningkat seiring pertumbuhan penduduk dan meningkatnya kebutuhan hidup akan pengiriman barang dilakukan agar terciptanya pembangunan bagi suatu bangsa dalam berbagai aspek kehidupan. Dengan demikian perdagangan memiliki peranan yang baik untuk mendukung pembangungan ekonomi di Indonesia ${ }^{1}$.

Sejalan dengan perkembangan ilmu pengetahuan dan perekonomian di Indonesia terutama dalam meningkatnya produksi barang dan jasa, maka dalam hal ini penting sekali adanya sarana pengiriman barang guna mendukung mobilitas barang dan jasa dari suatu tempat ke tempat lainnya, salah satunya sarana yang diperlukan ialah adanya pengangkutan. Sebagai negara kepulauan dan negara berkembang Indonesia memiliki hubungan dengan luar negeri maka dari itu Indonesia memerlukan jasa pengiriman/pengangkutan agar mampu menghubungkan pulau yang satu dengan pulau-pulau lainnya dan juga negara lain. Kondisi inilah yang mengakibatkan pentingnya kehadiran dari jasa pengiriman/pengenkutan. ${ }^{2}$

Banyaknya penduduk yang saling mengirimkan barang dari tempat-tempat yang jauh membuat perkembangan perusahaan jasa ekspedisi di Indonesia sangat berkembang pesat, terbukti dengan banyaknya pengguna pengguna jasa ekspedisi, bukti ini melahirkan banyaknya perusahan-perusahaan penyedia jasa ekspedisi seperti, Pos Indonesia, Jalur Nugraha Ekakurir (JNE), J\&T Express, SiCepat, dll. ${ }^{3}$

Pengaturan jasa ekspedisi ini pada awalnya diatur dalam Undang-Undang Nomor 6 Tahun 1984 tentang Pos, dimana dalam Pasal 3 dijelaskan bahwa kegiatan Pos diselenggarakan oleh negara, dan kegiatan Pos yang dimaksud ialah pelayanan terhadap lalu lintas surat Pos, uang, barang, dan pelayanan jasa lainnya yang ditetapkan oleh Menteri, yang dilaksanakan oleh badan yang mempunyai tugas melaksanakan Pos dan Giro. Dalam artian pada awalnya kegiatan jasa pengiriman ini hanya dapat dilaksanakan oleh negara/Badan Usaha Milik Negara yang dalam hal ini adalah PT. Pos (Persero). Namun seiring berkembangnya zaman, Undang-Undang Nomor 6 Tahun 1984 dicabut dan diganti dengan Undang-

1 Nafi' Mubarok, Buku Diktat Hukum Dagang, Fakultas Syariah dan Hukum Universitas Sunan Ampel, Surabaya, 2016, hlm. 101.

2 R. Soekardono, Hukum Dagang Indonesia Jilid 2 Hukum Pengangkutan di Darat, Rajawali Press, Jakarta. 1981, hlm.4.

${ }^{3}$ Hawani, Tanggung Jawab PT. Tiki JNE Dalam Pengiriman Barang Terhadap Konsumennya (Studi pada PT. TIKI JALUR NUGRAHA EKAKURIR Cab. Bandar Lampung), Jurnal Fakultas Hukum Universitas Lampung, Bandar Lampung, 2010, hlm. 2. 
Undang Nomor 38 Tahun 2009 tentang Pos. Dalam Pasal 4 ayat (2) dijelaskan bahwa Penyelenggaraan Pos dilakukan oleh badan usaha yang berbadan hukum Indonesia. Maka jika dilihat dari Pasal ini penyelenggaraaan Pos tidak hanya dilakukan oleh Badan Usaha Milik Negara saja akan tetapi dapat dilakukan oleh Badan Usaha Milik daerah, Badan Usaha Milik Swasta dan Koperasi. ${ }^{4}$

Dalam pelaksanaan pengiriman barang maka pihak pertama sebagai penyedia jasa ekspedisi dan pihak kedua sebagai pengguna jasa ekspedisi saling terikat dalam suatu perjanjian. Secara umum perjanjian diatur dalam Pasal 1313 KUH Perdata yang memberikan penjelasan bahwa suatu persetujuan merupakan suatu perbuatan dimana satu orang ataupun lebih mengikatkan dirinya terhadap satu orang ataupun lebih. Di dalam sebuah kontrak atau perjanjian terdapat halhal yang harus dipenuhi atau terdapat syarat sahnya perjanjian seperti yang telah ditentukan dalam Pasal 1320 KUH Perdata yang terbagi sebagai berikut: ${ }^{5}$

a. Sepakat mereka yang mengikatkan dirinya;

b. Kecakapan untuk membuat suatu perikatan;

c. Suatu hal tertentu;

d. Sebab yang halal.

Dengan dipenuhinya 4 (empat) syarat sahnya perjanjian di atas, maka perjanjian antara para pihak tersebut dapat dikatakan sah dan mengikat untuk para pihak yang melaksanakannya. Dalam melaksanakan sesuatu perjanjian terdapat azasazas yang harus dimengerti oleh para pihak yaitu, azas konsensualisme, azas kekuatan mengikatnya kontrak, azas kebebasan berkontrak, dan azas itikad baik.

Perjanjian pengiriman barang terjadi ketika adanya kesepakatan antara kedua belah pihak, maka secara otomatis timbul hak dan kewajiban bagi para pihak. Hak dan kewajiban pada perjanjian ini terdapat pada bagian halaman belakang resi pengiriman yang telah dirinci dan dibuat secara sepihak oleh pihak JNE. Perusahaan JNE melakukan kewajibannya selaku perantara dalam pengiriman barang dan bertanggung jawab atas apapun yang terjadi pada barang tersebut. Di lain sisi pihak pengguna JNE ini diwajibkan membayarkan sejumlah uang sebagai ongkos kirim yang sudah ditentukan oleh pihak JNE, tergantung pada jarak tujuan yang diinginkan oleh pihak pengirim.

Mekanisme pelayanan dalam pengiriman barang yang dilakukan JNE bermula saat konsumen datang ke pihak JNE dengan memberikan sesuatu barang yang telah dipersiapkan oleh pengguna untuk dikirim ketujuan yang diingikan. Pada saat itu pihak JNE akan melakukan pengecekan atas barang tersebut, kemudian pihak JNE akan memberikan suatu dokumen atau surat perjanjian pengiriman barang yang selanjutnya diberikan dan harus ditandatangani oleh

${ }^{4}$ Wahyu Sudrajat Muhammad, Implementasi Asas Kebebasan Berkontrak Kaitannya Dengan Perlindungan Konsumen Dalam Perjanjian Baku (Studi pada perjanjian pengiriman barang PT. Tiki), Jurnal Universitas Diponegoro, Semarang, 2012, hlm. 3.

${ }_{5}^{5}$ Suharnoko, Hukum Perjanjian, Teori dan Analisa Kasus, Kencana Prenada Media Group, Jakarta, 2007, hlm. 1 . 
pengirim, penandatanganan yang dilakukan pengirim mengandung arti bahwa pengirim telah menyetujui syarat-syarat atau klausul-klausul baku baik mengenai syarat, ketentuan, akibat dan risiko dari pengiriman barang tersebut.

Perjanjian pengiriman barang antara pihak JNE dengan konsumen didasarkan pada perjanjian baku, dimana perjanjian baku telah dibuat secara sepihak oleh JNE. Perjanjian baku adalah suatu rancangan perjanjian tertulis yang ditulis tanpa mendiskusikan isinya dan biasanya disalurkan ke dalam sejumlah perjanjian tidak terbatas yang sifatnya tertentu. Perjanjian baku dapat diartikan sebagai perjanjian yang isinya telah dibakukan terlebih daahulu dalam bentuk formulir. Salah satu pihak tidak mempunyai pilihan kecuali menerima atau menolak perjanjian tersebut. ${ }^{6}$

Pasal 1 angka 10 Undang-Undang No 8 Tahun 1999 tentang Perlindungan Konsumen memberikan penjelasan perjanjian baku sebagai setiap aturan atau ketentuan dan syarat-syarat yang sudah dipersiapkan serta ditetapkan terlebih dulu secara sepihak oleh pelakon usaha yang dituangkan dalam suatu dokumen serta/ataupun perjanjian yang mengikat serta harus dipenuhi oleh konsumen. Perjanjian baku juga diartikan sebagai perjanjian yang hampir semua klausulklausulnya dibakukan oleh pemakainya serta pihak yang lain pada dasarnya hanya mampu menyetujui dan tidak memiliki kesempatan untun melakukan perundingan atau meminta perubahan. ${ }^{7}$

Pelaksanaan perjanjian pengiriman barang lewat JNE tidak senantiasa berjalan mudah, misalnya barang yang sudah disepakati oleh kedua belah pihak untuk dikirim ternyata tidak sampai ke tujuan dengan tepat waktu atau mengalami keterlambatan pengiriman barang yang menimbulkan hilangnya manfaat dari barang tersebut. Salah satu contohnya keterlambatan pengiriman dokumen ataupun makanan, dimana konsumen melakukan perjanjian pengiriman barang menggunakan layanan Reguler dengan perkiraan waktu 4-5 hari namun pengiriman dokumen ataupun makanan itu mengalami keterlambatan yang menyebabkan kerugian atau hilangnya manfaat dari barang tersebut. Ketentuan mengenai estimasi waktu pengiriman ini tidak dicantumkan dalam perjanjian melainkan hanya perkiraan barang kiriman itu sampai ditangan konsumen. Apabila keterlambatan itu dikarenakan oleh pihak JNE maka konsumen selaku pengguna jasa ekspedisi berhak meminta ganti kerugian kepada pihak JNE atas kesalahan/kelalaian yang dilakukan oleh pihak JNE tersebut.

Perjanjian pengiriman barang antara perusahaan dengan pihak pengirim barang bersifat timbal balik. ${ }^{8}$ Perjanjian timbal balik ini meletakkan hak dan kewajiban kepada kedua belah pihak yang membuat perjanjian. Dalam perihal ini

\footnotetext{
${ }^{6}$ Mariam Darus Badrulzaman, Aneka Hukum Bisnis, Alumni, Bandung, 1994, hlm. 47.

${ }^{7}$ Celina Tri Siwi Kristiyanti, Hukum Perlindungan Konsumen, Sinar Grafika, Jakarta, 2008, hlm. 139.

${ }^{8}$ Siti Nurbaiti dalam Rinitami Njatrijan, Hukum Transportasi, Undip Law Press, Semarang, 2015, hlm. 9 .
} 
hak serta kewajiban para pihak dalam pelaksanaan pengiriman barang telah diatur di dalam Undang-Undang Nomor 8 Tahun 1999 tentang Perlindungan Konsumen. Perlindungan terhadap hak-hak bagi pengirim dan penerima selaku pengguna jasa di Indonesia telah diatur sejak lama. Hukum perlindungan konsumen ialah hukum yang berlaku untuk melindungi hak-hak bagi pengguna jasa tersebut. Hukum perlindungan konsumen bertujuan untuk mencegah tindakan-tindakan pelaku usaha yang merugikan konsumen. Pemerintah Indonesia memberikan aturan mengenai tanggung jawab pelaku usaha apabila terjadi kerusakan barang ataupun tindakan yang merugikan konsumen yang dicantumkan dalam Pasal 19 UndangUndang Nomor 8 Tahun 1999 tentang Perlindungan Konsumen. Perlindungan konsumen ini diharapkan mampu memberikan pengertian kepada masyarakat Indonesia untuk lebih memahami hak dan kewajiban yang didapatkan terhadap pelaku usaha, dimana perlindungan konsumen ini berperan untuk menumbuhkan harkat martabat, menumbuhkan akan kesadaran, wawasan, ketertarikan, keahlian, dan kebebasan konsumen untuk melakukan perlindungan terhadap dirinya serta menumbuhkan sikap pelaku usaha yang bertanggung jawab. ${ }^{9}$

Penelitian ini bertujuan untuk memberikan informasi kepada konsumen mengenai perlindungan yang didapat jika terjadi wanprestasi dalam melakukan pengiriman barang dan meningkatkan kesadaran dari pelaku usaha tentang pentingnya perlindungan terhadap konsumen sehingga diharapkan timbul sikap yang jujur, amanah dan bertanggung jawab dalam melakukan kegiatan usaha. Berdasarkan latar belakang diatas peneliti mengkaji mengenai bagaimanakah hak dan kewajiban para pihak dalam perjanjian pengiriman dan bagaimanakah bentuk tanggung jawab PT. JNE Cabang Stabat ketika terjadinya keterlambatan ataupun wanprestasi dalam pengiriman barang.

\section{METODE PENELITIAN}

Rumusan masalah dalam penelitian ini mencakup tentang hak dan kewajiban para pihak dalam perjanjian pengiriman barang oleh PT. JNE Cabang Stabat dan bentuk tanggung jawab PT. JNE Cabang Stabat apabila terjadi keterlambatan pengiriman barang. Jenis penelitian yang digunakan ialah penelitian yuridis empiris dengan pendekatan kepustakaan dan lapangan. Pendekatan kepustakaan digunakan untuk memperoleh data sekunder yang bersifat teoritis, sedangkan pendekatan lapangan dilakukan untuk memperoleh data primer lewat proses wawancara dengan responden dan informan. Bahan hukum yang digunakan yaitu bahan hukum primer (KUH Perdata, UU No 8 Tahun 1999 tentang Perlindungan Konsumen, UU No 40 Tahun 2007 tentang Perseroan Terbatas), bahan hukum sekunder (buku-buku dan tulisan-tulisan ilmiah hukum yang terkait dengan objek penelitian), dan bahan hukum tersier (kamus umum dan ensiklopedia, majalah dan

${ }^{9}$ Gunawan Widjaja dan Ahmad Yani, Hukum Tentang Perlindungan Konsumen, Cetakan Kedua, Gramedia Pustaka Utama, Jakarta, 2001, hlm. 2.

Jurnal Ilmiah Mahasiswa FH: Volume IV Nomor 1 (Januari, 2021) | 57 
surat kabar dst), Analisis data dilakukan secara kualitatif, analisis data dilakukan sejak awal dan terus berjalan sepanjang proses penelitian berlangsung (cycling process), bahan hukum (data) hasil pengolahan dari data sekunder tersebut dianalisis secara kualitatif yaitu dengan menginterprestasikan data dalam bentuk kalimat secara terperinci dan sistematis, kemudian dilakukan pembahasan. Bersumber pada hasil pembahasan setelah itu diambil kesimpulan secara induktif sebagai jawaban terhadap permasalahan yang diteliti. Sifat penelitian ini bersifat deskriptif, dimana penelitian ini bertujuan terhadap suatu bentuk penelitian yang ditujukan untuk memberikan gambaran fenomena-fenomena yang ada, baik menggambarkan individu, keadaan, gejala atau penyebaran suatu gejala dan hubungan tertentu, serta berupaya menggambarkan fenomena penelitian terhadap fenomena Tanggung Jawab Perusahaan Jasa Ekspedisi Atas Keterlambatan Pengiriman Barang di PT. JNE Cabang Stabat. ${ }^{10}$

\section{HASIL PENELITIAN DAN PEMBAHASAN}

\section{a. Hak dan Kewajiban Para Pihak Dalam Pengiriman Barang}

Dengan adanya hubungan hukum yang terjadi antara pihak pengirim dengan pihak JNE dalam melakukan perjanjian pengiriman barang, maka hal ini meyebabkan timbulnya konsekuensi yuridis bagi pihak pengirim maupun pihak JNE dalam perjanjian pengiriman barang ini, yaitu berupa hak-hak dan kewajiban. Hak dan kewajiban para pihak dalam perjanjian pengiriman barang di PT. JNE Cabang Stabat terdapat pada syarat-syarat standar pengiriman yang terletak pada resi pengiriman. Hak dan kewajiban para pelaku usaha serta konsumen juga terdapat dalam UndangUndang Nomor 8 Tahun 1999 tentang Perlindungan Konsumen.

Bila dilihat hak serta kewajiban para pihak yang terdapat dalam ketentuan standar pengiriman yang sudah ditentukan oleh PT. JNE Cabang Stabat maka diketahui dalam beberapa hal sesungguhnya PT. JNE telah diuntungkan dalam perjanjian pengiriman barang tersebut. Misalnya perihal yang berkaitan dengan prosedur dan jangka waktu, jika dalam pengiriman merupakan sebuah makanan, dimana pihak JNE melakukan wanprestasi dengan mengantarkan barang melebihi estimasi yang sudahp[ ditentukan dan menyebabkan makanan tersebut mengalami kebasian, maka dalam hal ini pihak JNE melepaskan tanggung jawabnya sebagai jasa pengiriman, pihak JNE juga tidak dapat digugat secara perdata. Perjanjian pengiriman barang pada PT. JNE Cabang Stabat merupakan bentuk perjanjian baku, dimana perjanjian baku ialah perjanjian yang hampir keseluruhan klausula-klausulanya sudah terlebih dahulu dibakukan oleh pemakainya dan pihak lainnya pada dasarnya tidak memiliki kesempatan untuk membincangkan atau meminta pergantian. ${ }^{11}$ Hadyan Yunhas Purba berpendapat bahwa klausula baku dalam perjanjian pengiriman barang JNE sah-sah saja dilakukan, namun sering sekali klausula baku ini diabaikan oleh konsumen. Konsumen biasanya tidak membaca ataupun memahami hak dan kewajibannya yang ada dalam klausula baku, bisa saja hak dan kewajiban dari konsumen itu dipangkas oleh pihak pembuat.

\footnotetext{
${ }^{10}$ Lexy Maleong, Metode Penelitian Kualitatif, Remaja Rosdakarya, Bandung, 2012, hlm. 5.

${ }^{11}$ Sutan Remi Sjahdeini, Kebebasan Berkontrak dan Perlindungan yang Seimbang Bagi Para Pihak Dalam Perjanjian Kredit Bank Di Indonesia, Institut Bank Indonesia, Jakarta, 1993, hlm. 66.
} Jurnal Ilmiah Mahasiswa FH: Volume IV Nomor 1 (Januari, 2021) | 58 
Dalam membuat klausula baku harus diperhatikan agar cocok dengan ketentuan Pasal 18 Undang-Undang Nomor 8 Tahun 1999 tentang Perlindungan Konsumen. Menurut Hadyan, klausula baku diadakan untuk menjaga kepraktisan dan efisiensi dalam melakukan perjanjian. ${ }^{12}$

Apabila kita mengacu pada hak dan kewajiban dari pihak JNE Cabang Stabat yang terdapat dalam ketentuan standar pengiriman maka akan ada perbedaan dengan hak dan kewajiban yang telah diatur dalam UU No 8 Tahun 1999 tentang Perlindungan Konsumen, dimana perbedaan tersebut terletak dalam:

a. Kiriman, yaitu:

Syarat Standar Pengiriman yang berada di halaman belakang resi pengiriman mengatur hak JNE untuk tidak menerima atau melakukan pengiriman atas barang-barang berbahaya seperti narkotika dan barang sejenisnya, sedangkan di dalam Undang-Undang Perlindungan Konsumen tidak mengendalikan secara spesifik mengenai barang-barang yang dilarang pada pengiriman. UndangUndang Perlindungan Konsumen lebih mengatur kepada itikad baik dari para pihak dalam melakukan pengiriman barang.

b. Ganti kerugian, yaitu:

Undang-Undang Perlindungan Konsumen mengatur perihal ganti kerugian apabila barang dan/atau jasa yang diterima atau dimanfaatkan tidak cocok dengan perjanjian, namun bila dilihat dari Syarat Standar Pengiriman bentuk ganti kerugian yang diberikan oleh pihak JNE hanya diberikan kepada pengguna layanan produk tertentu, artinya tidak semua pengguna dapat meminta ganti kerugian walaupun kesalahan tersebut disebabkan oleh pihak JNE itu sendiri, tentu saja ini merupakan suatu pembatasan tanggung jawab yang dilakukan oleh JNE.

\section{b. Tanggung Jawab PT. JNE Atas Keterlambatan Pengiriman Barang}

Tanggung jawab ialah kesadaran manusia mengenai tingkah lakunya maupun tindakannya baik disengaja ataupun tidak, Dalam kasus pelanggaran hak konsumen, harus diketahui secara hati-hati dalam menentukan siapa yang harus bertanggungjawab dan seberapa besar tanggung jawab yang dilimpahkan kepada pihak-pihak terkait. ${ }^{13}$ Keterlambatan dalam proses pengiriman barang yang dilakukan perusaahan JNE merupakan suatu perbuatan wanprestasi, dimana JNE sebagai jasa pengiriman barang tidak dapat memenuhi prestasinya dengan mengantarkan barang melebihi estimasi yang sudah ditentukan sebelumnya. Keterlambatan yang disebabkan kelalaian/kesalahan pihak JNE tentu saja merugikan konsumen, terlebih-lebih barang tersebut sangat dibutuhkan oleh konsumen agar segera digunakan, keterlambatan ini tentu saja bisa mengurangi ataupun menghilangkan manfaat dari barang tersebut. Keterlambatan pengiriman barang menjadi tanggung jawab PT. JNE sebagai pihak pengirim yang melakukan tindakan wanprestasi untuk mengganti kerugian yang dialami konsumen, sebagaimana yang telah diatur dalam Pasal 1246 KUH Perdata yang menyatakan biaya, ganti rugi, dan bunga yang boleh dituntut kreditur terdiri atas kerugian yang telah dideritanya dan keuntungan yang sedianya dapat diperolehnya.

${ }^{12}$ Hadyan Yunhas Purba, Dosen Fakultas Hukum Universitas Sumatera Utara, Wawancara, 03 Maret 2021.

${ }^{13}$ Shidarta, Hukum Perlindungan Konsumen, Grasindo, Jakarta, 2000, hlm. 59. Jurnal Ilmiah Mahasiswa FH: Volume IV Nomor 1 (Januari, 2021) | 59 
Hari Susilo Sakti sebagai Kepala JNE Cabang Stabat memberikan tanggapan apabila terjadi keterlambatan, maka pihak JNE akan memberikan ganti kerugian sebesar ongkos kirim barang tersebut. Penggantian kerugian tidak berlaku bagi semua produk layanan tetapi hanya berlaku pada layanan Yakin Esok Sampai (YES) dan Super Speed (SS). Apabila keterlambatan itu menggunaan layanan lain seperti Reguler. Ongkos Kirim Ekonomis (OKE) ataupun Trucking maka tidak ada bentuk ganti kerugian yang diterima konsumen.

Permasalahan lainnya pada pengiriman makanan yang mengalami keterlambatan dan menyebabkan kebasian pada makanan tersebut maka pihak JNE akan bertanggung jawab dengan syarat makanan tersebut harus diasuransikan kebasiannya terlebih dahulu, menggunakan layanan YES, dan minimal jangka waktu kebasiannya 3 hari dari tanggal kirim. Pihak JNE dan penerima akan membuat perjanjian dimana pihak pengirim memberitahu harga makanan yang akan dikirimkan, dan apabila keterlambatan itu terjadi yang mengakibatkan kebasian pada makanan yang dikirimkan maka pihak JNE akan mengganti kerugian seharga makanan tersebut. ${ }^{14}$ Pada proses pembuktian pihak yang harus bertanggung jawab bila terjadi keterlambatan pengiriman harus bisa membuktikan bahwa sudah melakukan tugasnya sesuai prosedur. Apabila pihak PT. JNE dapat membuktikan bahwa kesalahan itu bukan dikarenakan oleh pihak PT. JNE, tetapi kesalahan itu dilakukan oleh pihak pengirim (dalam hal ini armada pengiriman) atau terdapat kondisi memaksa (force Majeure) yang menyebabkan barang tersebut terlambat untuk sampai ketujuan, maka hal ini mengakibatkan hilangnya kewajiban pihak PT. JNE untuk mengganti kerugian konsumen. Hal ini sebagaimana yang terdapat dalam Pasal 468 ayat (2) KUHD bahwa "Si pengangkut diwajibkan mengganti segala kerugian, yang disebabkan barang tersebut seluruhnya atau sebagai tidak dapat diserahkannya, atau karena terjadi kerusakan pada barang itu, kecuali apabila dibuktikannya bahwa tidak diserahkannya barang atau kerusakan tadi disebabkan oleh suatu malapetaka yang selayaknya tidak dapat dicegah maupun dihindarkannya, atau cacat dari pada barang tersebut, atau oleh kesalahan dari si yang mengirimkannya”. Penggantian kerugian yang diakibatkan karena keterlambatan hanya diberikan kepada pengguna layanan Yakin Esok Sampai (YES), tetapi untuk pengguna layanan lain seperti Reguler, Ongkos Kirim Ekonomis (OKE) dan JNE Trucking tidak ada diberi ganti kerugian, tentu saja tindakan ini merugikan para konsumen dan melanggar ketentuan Undang-Undang, dimana pihak JNE berusaha untuk menghindar dari tanggung jawabnya sebagai jasa pengiriman barang, bila kita lihat dari Pasal 7 huruf f Undang-Undang Nomor 8 Tahun 1999 tentang Perlindungan Konsumen, tertulis secara jelas bahwa kewajiban pelaku usaha untuk memberi kompensasi, ganti rugi dan/atau penggantian atas kerugian akibat penggunaan, pemakaian dan pemanfaatan barang dan/atau jasa yang diperdagangkan. Pasal ini menjelaskan bahwa bentuk ganti kerugian yang diberikan kepada konsumen tidak boleh dibatasi oleh beberapa layanan saja, melainkan apabila terjadi keterlambatan yang merugikan pihak konsumen yang disebabkan kelalaian pihak JNE maka dalam hal ini seharusnya menjadi tanggung jawab dari PT. JNE Cabang Stabat tanpa melihat layanan produk yang dipilih oleh konsumen untuk melakukan pengiriman barang.

\section{KESIMPULAN}

${ }^{14}$ Hari Susilo Sakti, Kepala JNE Cabang Stabat, Wawancara, 02 Maret 2021 Jurnal Ilmiah Mahasiswa FH: Volume IV Nomor 1 (Januari, 2021) | 60 
Bersumber pada hasil penelitian diatas dapat disimpulkan bahwa dalam melakukan perjanjian pengiriman barang pada PT. JNE Cabang Stabat tentu saja akan timbul hak dan kewajiban dari pihak pengirim maupun JNE. Hak dan kewajiban ini saling berdampingan, jika salah satu pihak tidak melaksanakan hak maupun kewajibannya maka akan timbul wanprestasi dalam perjanjian tersebut. Hak dan kewajiban pihak pengirim dan pihak JNE ini diatur di dalam Undang-Undang-Nomor 8 Tahun 1999 tentang Perlindungan Konsumen, dan diatur juga dalam Syarat Standar Pengiriman Barang yang berada pada halaman belakang resi pengiriman JNE. proses pengiriman barang tentu saja tidak senantiasa berjalan dengan lancar, terdapat kendala-kendala yang dapat menyebabkan keterlambatan dalam pengiriman barang seperti adanya kendala armada pengiriman, kendala penarikan waktu di kota tujuan, tentu saja keterlambatan pengiriman barang ini merugikan konsumen selaku pengguna Jasa JNE. Keterlambatan pengiriman barang merupakan tanggung jawab dari pihak JNE dengan syarat keterlambatan itu disebabkan kesalahan dari pihak JNE itu sendiri, pihak JNE akan memberikan ganti kerugian kepada pihak konsumen atas keterlambatan pengiriman barang tersebut, namun perlu diketahui bahwa ganti kerugian yang diakibatkan oleh keterlambatan tidak semata-mata menjadi tanggung jawab pihak JNE. Pertanggungjawaban pihak JNE terhadap keterlambatan hanya berlaku pada layanan Yakin Esok Sampai (YES) dam Super Speed (SS), dan tidak berlaku pada layanan lain seperti Reguler, JNE Truncking dan Ongkos Kirim Ekonomis (OKE). Pihak JNE akan mengganti kerugian terhadap pengguna layanan Yakin Esok Sampai dan Super Speed (SS) sebesar ongkos kirim yang telah ditentukan sebelumnya.

\section{DAFTAR PUSTAKA}

Darus Badrulzaman, Mariam, 1994, Aneka Hukum Bisnis, Bandung: Alumni.

Kristiyanti, Celina Tri Siwi, 2008, Hukum Perlindungan Konsumen, Jakarta: Sinar Grafika.

Maleong, Lexy, 2012, Metode Penelitian Kualitatif, Remaja Rosdakarya, Bandung

Mubarok, N, 2016, Buku Diktat Hukum Dagang, Surabaya: Fakultas Syariah dan Hukum Universitas Sunan Ampel.

Nurbaiti, S, dalam Rinitami Njatrijan, 2015, Hukum Transportasi, Semarang: Undip Law Press.

Soekardono, R 1981, Hukum Dagang Indonesia jilid 2 Hukum Pengangkutan di Darat, Jakarta: Rajawali Press.

Sjahdeini, Sutan Remi, 1993, Kebebasan Berkontrak dan Perlindungan yang Seimbang Bagi Para Pihak Dalam Perjanjian Kredit Bank Di Indonesia, Jakarta: Institut Bank Indonesia.

Shidarta, 2000, Hukum Perlindungan Konsumen, Jakarta: Grasindo.

Suharnoko, 2007, Hukum Perjanjian, Teori dan Analisa Kasus, Jakarta: Kencana Prenada Media Group.

Widjaja, G, dan Ahmad Yani, Hukum Tentang Perlindungan Konsumen, Cetakan Kedua, Gramedia Pustaka Utama, Jakarta,

Hawani, 2010, Tanggung Jawab PT. Tiki JNE Dalam Pengiriman Barang Terhadap Konsumennya (Studi pada PT. TIKI JALUR NUGRAHA EKAKURIR Cab. Bandar Lampung), Bandar Lampung: Jurnal Fakultas Hukum Universitas Lampung. 
Wahyu Sudrajat Muhammad, 2012, Implementasi Asas Kebebasan Berkontrak Kaitannya Dengan Perlindungan Konsumen Dalam Perjanjian Baku (Studi pada perjanjian pengiriman barang PT. Tiki), Semarang: Jurnal Universitas Diponegoro. 